\title{
The Impact of Training and Development on Employee Performance and Effectiveness: A Case Study of District Five Administration Office, Bole Sub-City, Addis Ababa, Ethiopia
}

\author{
Abeba Mitiku Asfaw ${ }^{1}$, Mesele Damte Argaw ${ }^{2 *}$, Lemessa Bayissa ${ }^{3}$ \\ ${ }^{1}$ Addis Ababa City Government, Addis Ababa, Ethiopia \\ ${ }^{2}$ Private Health Sector Program, Addis Ababa, Ethiopia \\ ${ }^{3}$ Civil Service University, Addis Ababa, Ethiopia \\ Email:kidistmitiku@gmail.com, “mdamte5@gmail.com, lemessakoras@gmail.com
}

Received 2 November 2015; accepted 4 December 2015; published 7 December 2015

Copyright (C) 2015 by authors and Scientific Research Publishing Inc.

This work is licensed under the Creative Commons Attribution International License (CC BY).

http://creativecommons.org/licenses/by/4.0/

(c) (i) Open Access

\begin{abstract}
The focus of this study was to determine the impact of training and development on the employees' performance and effectiveness at District Five Administration Office, Addis Ababa, Ethiopia. In this study we employed cross sectional institutional based quantitative research method. Data were collected using Likert's scale tool from 100 employees after selecting participants using systematic random sampling technique. Ninety-four complete questionnaires with a response rate of $94 \%$ were considered during analysis. Training and development had positively correlated and claimed statistically significant relationship with employee performance and effectiveness. It is recommended that District Five Administration Office shall maintain providing employee training and development activities and ensure the participation of employees in planning, need or skill deficit identification and evaluation of training and development programs.
\end{abstract}

\section{Keywords}

Training, Development, Performance, Effectiveness, Ethiopia

\section{Introduction}

\subsection{Background}

Human resources (Armstrong, 2009) have played a significant role in the economic development in most devel-

${ }^{*}$ Corresponding author.

How to cite this paper: Asfaw, A.M., Argaw, M.D. and Bayissa, L. (2015) The Impact of Training and Development on Employee Performance and Effectiveness: A Case Study of District Five Administration Office, Bole Sub-City, Addis Ababa, Ethiopia. Journal of Human Resource and Sustainability Studies, 3, 188-202. http://dx.doi.org/10.4236/jhrss.2015.34025 
oped countries [1]. Developing countries like Ethiopia, can adopt these lessons to their growing economy. To manage an organization both large and small requires staffing them with competent personnel. The formal educational system does not adequately teach specific job skills for a position in a particular organization. Few employees have the requisite skills, knowledge, abilities and competencies needed to work effectively. As a result, many require extensive training to acquire the necessary aforementioned requisites to be able to make substantive contribution towards the organization's growth.

Training is imparting a specific skill to do a particular job while development deals with general enhancement and growth of individual skill and abilities through conscious and unconscious learning [2] [3]. The main purpose of training and development is by improving the employee competencies so that organizations can maximize efficiency and effectiveness of their human assets [4]. Armstrong (2009) clearly stated in his book that organizations could benefit from training and development through winning the "heart and minds of" their employees to get them to identify with the organization, to exert themselves more on its behalf and to remain with the organization [1].

If employees are to experience flexibility and effectiveness on the job, they need to acquire and develop knowledge and skills, and if they are to believe that they are valued by the organization they work for, then they need to see visible signs of management's commitment to their training and career needs [5]. Training and development are the processes of investing in people so that they are equipped to perform well. These processes are part of an overall human resource management approach that hopefully will result in people being motivated to perform [5] [6].

It goes without saying therefore that the training and development of employees are an issue that has to be faced by every organization. However, the amount, quality and quantity of training carried out vary enormously from organization to organization. According to Cole (2002), factors influencing the quantity and quality of training and development activities include: the degree of change in the external environment, the degree of internal change, the availability of suitable skills within the existing work-force and the extent to which management see training as a motivating factor in work [3].

Many organizations meet their needs for training in an ad hoc and haphazard way. Training in these organizations is more or less unplanned and unsystematic. Other organizations however set about identifying their training needs, then design and implement training activities in a rational manner, and finally assess results of training [7]-[9].

It is worth noting that Ethiopia has a large numbers of not-for-profit organizations that are employing the significant number of human resources with diversified skills. Addis Ababa is the capital city of Ethiopia with an area of 530 square kilometer $\left(\mathrm{km}^{2}\right)$ and a total population of more than 3 million. It has 10 sub-cities and 160 districts (Woredas). Currently, district is the smallest administrative structure mandated to serves large size and diversified sections of the population [10]. To the knowledge of the investigators, there are no studies which examine the impact of training and development on employee's performance and effectiveness conducted in District Administration Office level in Addis Ababa, Ethiopia. However, despite the execution of civil service reform, many clients frequently complain on the service they received from these offices. Since the District Administrative Offices are newly established structure, the issue could be attributable to employee training and development activities.

\subsection{Literature Review}

\subsubsection{Overview of Training}

One major area of the Human Resource Management function of particular relevance to the effective use of human resources is training and development [11]. Few people these days would argue against the importance of training as a major influence on the success of an organization. Employees are a crucial and expensive resource [12]. In order to sustain effective performance, it is important to optimize the contribution of employees to the aims and goals of the organizations. The importance of training as a central role of management has been recognized by research studies. For instance, Jehanzeb and Beshir (2013), confer one contribution of an organization's manager is to give others vision and ability to perform [13].

The general movement towards downsizing, flexible structures of organizations and the nature of management moving towards the devolution of power to the workforce give increasing emphasis to an environment of coaching and support [6] [14]. Training is necessary to ensure an adequate supply of staff that is technically and 
socially competent and capable of career development into specialist departments or management positions. There is therefore a continual need for the process of staff development, and training fulfills an important part of this process. Training should be viewed therefore as an integral part of the process of total quality management [15].

\subsubsection{Human Resource Management}

For any organization to function effectively, it must have money, materials, supplies, equipment, ideas about the services or products to offer those who might use its outputs and finally people, which is the human resource, to run the organization. The effective management of people at work is Human Resource Management [1]. Human Resource Management has emerged as a major function in most organizations and is the focus for a wide-ranging debate concerning the nature of the contemporary employment relationships. Managing human resources is one of the key elements in the coordination and management of work organizations. Shen (2004) defines Human Resource Management as the involvement of all management decisions and actions that affect the nature of the relationship between the organization and its employees-the human resources. According to Shen generally management make important decisions daily that affect this relationship [11].

\subsubsection{Human Resource Management and Training}

McDowall et al. (2010) argue that the recognition of the importance of training in recent years has been heavily influenced by the intensification of competition and the relative success of organizations where investment in employee development is considerably emphasized [5]. They add that technological developments and organizational change have gradually led some employers to the realization that success relies on the skills and abilities of their employees, and this means considerable and continuous investment in training and development [16] [17]. It is the view of Beardwell and Holden (1993) that Human Resource Management concepts such as commitment to the organization and the growth in the quality movement have led senior management teams to realize the increased importance of training, employee development and long-term education. Such concepts require not only careful planning but a greater emphasis on employee development [9].

\subsubsection{Purpose, Process and Outcomes of Training}

According Cole (2002), in his book Personnel and Human Resource Management, training is a learning activity directed towards the acquisition of specific knowledge and skills for the purpose of an occupation or task [3]. The focus of training is the job or task for example, the need to have efficiency and safety in the operation of particular machines or equipment, or the need for an effective sales force to mention but a few.

To develop the desired knowledge, skills and abilities of the employees, to perform well on the job, requires effective training programs that may also effect employee motivation and commitment [4]. Employees can make or break their organizational reputation and profitability. And they are responsible for the bulk of the activities which can affect client satisfaction, the quality of the product and event [6].

According to Garavan (1997) and Berge et al. (2002) training is the planned and systematic modification of behavior through learning events, activities and programs which results in the participants achieving the levels of knowledge, skills, competencies and abilities to carry out their work effectively [7] [8]. A formal training program is an effort by the employer to provide opportunities for the employee to acquire job-related skills, attitudes and knowledge [18]. This means for any organization to succeed in achieving the objectives of its training program, the design and implementation must be planned and systematic, tailored towards enhancing performance and productivity.

Most organizations have long recognized the importance of training to its development. As new technology progresses, making certain jobs and skills redundant, an increasing emphasis is being placed on the need for a skilled and highly trained workforce. Many of the jobs being replaced by machines have been of an unskilled and semi-skilled nature, and this emphasizes the need for higher education and skills for those wishing to gain employment in the future. According to Blain (2009) research shows that in Europe, $44 \%$ of employees receive job-related technical skills training and 33\% receive information technology (IT) skills training. 18\% of employees have undertaken sales related training in the past year, while $25 \%$ have undertaken personnel development skills training, 21\% management skills training and 15\% leadership skills development [19].

\subsubsection{Metacognitive Theories}

Tajfel (1972) introduced the idea of social identity to theorize how people conceptualize themselves in inter- 
group contexts, how a system of social categorizations “creates and defines an individual's own place in society". He defined social identity as "the individual's knowledge that he belongs to certain social groups together with some emotional and value significance to him of this group membership [20]. Similarly, Hogg and Terry (2000) describe multiple factors which influence how people work; social identity theory portends to be aunifying theory of organizational behavior because what and how people think as members of social groups influences subsequent behavior and attitudes in social systems [21].

The social identities in organizations serve as important drivers of performance. How people think as members of groups affects the outcomes of learning interventions. Therefore, social identity is a key input to or driver of learning and performance in organizations. Since, people do the work of organizations in group settings [21].

\subsubsection{Objectives of the Study}

This study was intended to determine the impact of training and development on employee performance and effectiveness. The data were collected from employees such as technical officers, administrative, finance and other support staffs who tenured in District Five Administration Office, Bole sub-City of Addis Ababa City Government of Ethiopia. Hence, the following three hypotheses were put forth: $\mathrm{H}_{1}$ there was no difference on the mean score of employee performance by employee training and development status; $\mathrm{H}_{2}$ there was no difference on the mean score of organizational effectiveness by Employee performance and $\mathrm{H}_{3}$ there was no difference on the mean score on organizational effectiveness by employee training and development status.

\section{Methodology}

\subsection{Research Design}

The study was a survey type in the form of cross sectional study in which data were collected once across a population through random sampling technique.

\subsection{Target Population}

All employees of District Five Administration Office which comprise technical officers, administrative staffs, secretaries, archives, accountants, logistics staffs and office assistants were targets of the study.

\subsection{Sampling Size and Sampling Procedure}

The sample size was 100 , which was allocated to each profession and specialties using probability proportional to size. Sampling procedure: District Five Administration Office was selected with purposive sampling method. Study participants were selected using simple random sampling techniques after employing the payroll as sampling frame, with sampling interval $(k)$ of 2.

\subsection{Research Instrument}

Comprehensive research instruments were developed and pre-test was arranged in similar setup at District Four Administration Office of Bole Sub City. Amendments of the tool were made before the real data collection started.

\subsection{Administration of the Instrument}

A questionnaire was administered to the various groups of employees of the organizations. A total of 100 questionnaires were administered in the form of one to one interviewer by trained data collector.

\subsection{Analysis of Data}

In order to ensure completeness and logical consistency of responses, data editing was carried out each day by the researcher. Identified mistakes and data gaps were rectified as soon as possible. Once editing was done with, the data were analyzed using quantitative techniques. The analysis was done using Statistical Package for Social Sciences (SPSS IBM Version 20) [22]. The summary of result was presented using frequency distribution and percentages, which was used to determine the proportion of respondents choosing the various responses. Tables, 
charts and graphs were used to ensure easy understanding of the analyses. Pearson Correlation and Linear Regression statistical model were used to identify the causal relationship with dependent and independent variables. Bivariate analyses were employed to identify all the possible correlations for the dependent variable. And multivariable analysis was used to control the confounding factors in the process of identifying the real predictor variables. To claim statistical significance tests, the cut-off value set is $\mathrm{P}<0.05$.

\subsection{Reliability}

The tool was piloted using 20 (10 males and 10 females) employee of District Four Administration Office. The responses of respondents were scored and the reliability of the tool was determined using Cronbach's Alpha. According to the alpha value more than 0.6, shows that the scale can be considered reliable [14]. The tool has twelve questions i.e. 4 questions for training and development, 5 questions for Employee Performance and 3 questions for employee effectiveness. The result shows that the Cronbach's alpha ranges from 0.687 to 0.819 which show the scale is reliable.

\begin{tabular}{cccc}
\hline Ser No. & Variables & No of items & Alpha reliability \\
\hline 1 & Training and development & 4 & 0.687 \\
2 & Employee performance & 5 & 0.819 \\
3 & Organizational effectiveness & 3 & 0.799 \\
\hline
\end{tabular}

\subsection{Ethical Consideration}

Ethical clearance was obtained from Foundation for Academic Excellence Ministry (FAEM) and International Institute of Church Management (IICM) Institutional Review Board (IRB) and research ethics committee. Permission was granted by District Five Administration office. The full informed consent of participants was taken.

\subsection{Operational Definitions}

Development: refers to the capacity and capability building on an employee, and thus as of whole organization, to meet the standard performance level [23]. Effectiveness: getting desired outcome within defined resources [24]. Organizational effectiveness: is the measure of how successfully organizations achieve their missions through their core strategies [25]. Performance: is everything about the performance of employees in a firm or a company or an organization [6]. Training: Training refers to bridging the gap between the current performance and the standard desired performance [7].

\section{Results}

A total 100 employees were invited to be the part of this study but 94 completed questionnaires were included in the analysis with a response rate of $94.0 \%$. Table 1 depicted the socio-demographic characteristics of the respondents. Slightly greater than half $52.1 \%$ of the study participants were males. The majority $(61.7 \%)$ of the respondents was lies in the youngest age category within 18 - 29 years. The mean $( \pm \mathrm{SD})$ age of the respondents was $30.3( \pm 7.9)$ years, and the median age was 27.5 years. The age of participant's ranges 18 - 56 years. A little higher than half of the respondents (58.5\%) were single, followed by (34.0\%) were married. Slightly greater than half (51.1\%) of the participants were achieved Bachelor's degree level of education. A little lower than half of the respondent $40(42.6 \%)$ were tenured for less than three years. The mean with standard deviation lifetime service tenured was $6.5 \pm$ (7.1) years. One third 30 (31.9\%) of the respondent had earned a monthly salary which ranges from 1373 to 1719 ET Birr each month which was equivalent to USD amounting 68.65 to 85.95 (1 USD is equivalent to $20.00 \mathrm{ET}$ birr). The mean monthly salary of the respondents with standard deviation was $1885 \pm$ (790.9) ET Birr per month.

Figure 1 shows bins represented each method used to facilitate trainings by District Administration Office in the last three year. The most frequent method reported by 50 (59.5\%) respondents were demonstration or on job coaching and exercise. The second highly utilized method of training facilitation was reported by 27 (32.0\%) as lecture and the third most frequent method employed to facilitate training were reported by 20 (23.8\%) as seminar. 
Table 1. Soico-demographic information of about the respondents, Addis Ababa, April, 2014.

\begin{tabular}{|c|c|c|c|c|}
\hline $\mathbf{S} / \mathbf{N}$ & Category & Component & Frequency & Percentage \\
\hline \multirow[t]{3}{*}{1} & Gender & Male & 49 & 52.1 \\
\hline & & Female & 45 & 17.9 \\
\hline & & Total & 94 & 100.0 \\
\hline \multirow[t]{6}{*}{2} & Age in years & $18-29$ & 58 & 61.7 \\
\hline & & $30-39$ & 22 & 23.4 \\
\hline & & $40-49$ & 10 & 10.6 \\
\hline & & $50+$ & 4 & 4.3 \\
\hline & & Total & 94 & 100.0 \\
\hline & & \multicolumn{3}{|c|}{$\begin{array}{l}\text { NB: mean } \pm(S D)=30.3 \pm(7.9) \text { years, } \\
\text { median }=27.5 \text { years, range }(56-18)=38 \text { years }\end{array}$} \\
\hline \multirow[t]{5}{*}{3} & Mariatal status & Single & 55 & 58.5 \\
\hline & & Married & 32 & 34.0 \\
\hline & & Divorced & 4 & 4.3 \\
\hline & & Widowed & 3 & 3.2 \\
\hline & & Total & 94 & 100.0 \\
\hline \multirow[t]{7}{*}{4} & Educational achievements & Primary education & 3 & 3.2 \\
\hline & & Secondary education & 5 & 5.3 \\
\hline & & Certificate & 3 & 3.2 \\
\hline & & Diploma & 33 & 35.1 \\
\hline & & Bachelor’s degree & 48 & 51.1 \\
\hline & & Master's degree & 2 & 2.1 \\
\hline & & Total & 94 & 100.0 \\
\hline \multirow[t]{5}{*}{5} & Years of work experience & $1-3$ & 40 & 42.6 \\
\hline & & $4-6$ & 23 & 24.5 \\
\hline & & $7+$ & 31 & 33.0 \\
\hline & & Total & 94 & 100.0 \\
\hline & & Mean $\pm(S D)=6.5 \pm(7.1)$ & dian $=4$ year & $6-1)=35$ years \\
\hline \multirow[t]{6}{*}{6} & Monthly income in ET Birr ${ }^{*}$ & $<1373$ & 24 & 25.5 \\
\hline & & $1373-1719$ & 30 & 31.9 \\
\hline & & $1720-2249$ & 27 & 28.7 \\
\hline & & $2250+$ & 13 & 13.8 \\
\hline & & Total & 94 & 100.0 \\
\hline & & $\begin{array}{r}\text { Mean } \pm(\mathrm{SD})=188 \\
\text { range }\end{array}$ & $\begin{array}{l}\text { ) ET Birr, me } \\
\text { 395) }=4850 \mathrm{E}\end{array}$ & 19 ET birr, \\
\hline
\end{tabular}

NB: ${ }^{*} 1$ USD equivalent to 20 ET birr.

Employees were asked to provide their opinion on selected thematic area using a tool developed based on ordinal Likert scale with the least 1 and the highest 5 score [26]. The weighted average for various training and development, employee performance and effectiveness item assessed as depicted in Table 2. The first four variables were about training and development. Training need or skill deficient identified before training (2.48), knew the objective of the training (2.90), the training was applicable on their job (2.27), and the trainings were 
Table 2. Respondents Assessment of their employer status with regards training development, performance and effectiveness, Addis Ababa, April 2014.

\begin{tabular}{rcccccccc}
\hline \multirow{2}{*}{$\begin{array}{c}\text { Ser } \\
\text { No. }\end{array}$} & Question & Excellent & Very good & Good & Fair & Poor & \multicolumn{2}{c}{ Weighted } \\
\cline { 2 - 7 } & Fre (\%) & Fre (\%) & Fre (\%) & Fre (\%) & Fre (\%) & Mean & SD \\
\hline 1 & Need identified & $1(1.2)$ & $16(19.0)$ & $18(21.4)$ & $36(42.9)$ & $13(15.5)$ & 2.48 & 1.01 \\
2 & Knew objective & $8(9.5)$ & $8(9.5)$ & $15(17.9)$ & $21(25.4)$ & $32(38.1)$ & 2.90 & 1.05 \\
3 & Applicable on job & $4(4.8)$ & $25(29.8)$ & $20(23.8)$ & $29(34.5)$ & $6(7.1)$ & 2.27 & 1.32 \\
4 & Design to improve skill & $15(17.9)$ & $27(32.1)$ & $19(22.6)$ & $19(22.6)$ & $4(4.8)$ & 3.35 & 1.15 \\
5 & Improved quality & $4(4.8)$ & $21(25.0)$ & $16(19.0)$ & $28(33.3)$ & $15(17.9)$ & 2.65 & 1.17 \\
6 & Reduce accident & $6(7.1)$ & $6(7.1)$ & $17(20.2)$ & $24(28.6)$ & $31(36.9)$ & 2.44 & 1.19 \\
7 & Use new tools/machines & $5(6.2)$ & $12(114.3)$ & $20(23.8)$ & $25(29.8)$ & $22(26.2)$ & 2.19 & 1.21 \\
8 & Improved motivation & $4(4.8)$ & $13(15.5)$ & $16(19.0)$ & $40(47.6)$ & $11(13.4)$ & 2.28 & 1.05 \\
9 & Job satisfaction & $2(2.4)$ & $6(7.1)$ & $25(29.8)$ & $24(28.6)$ & $27(32.1)$ & 2.19 & 1.04 \\
10 & Increased production & $6(7.1)$ & $17(20.2)$ & $18(21.4)$ & $24(28.6)$ & $19(22.6)$ & 2.60 & 1.24 \\
11 & Reduced waste & $6(7.1)$ & $23(27.4)$ & $16(19.0)$ & $25(29.8)$ & $14(16.7)$ & 2.78 & 1.22 \\
12 & Added new capabilities & $4(4.8)$ & $17(20.2)$ & $22(26.2)$ & $27(32.1)$ & $14(16.7)$ & 2.64 & 1.12 \\
\hline
\end{tabular}

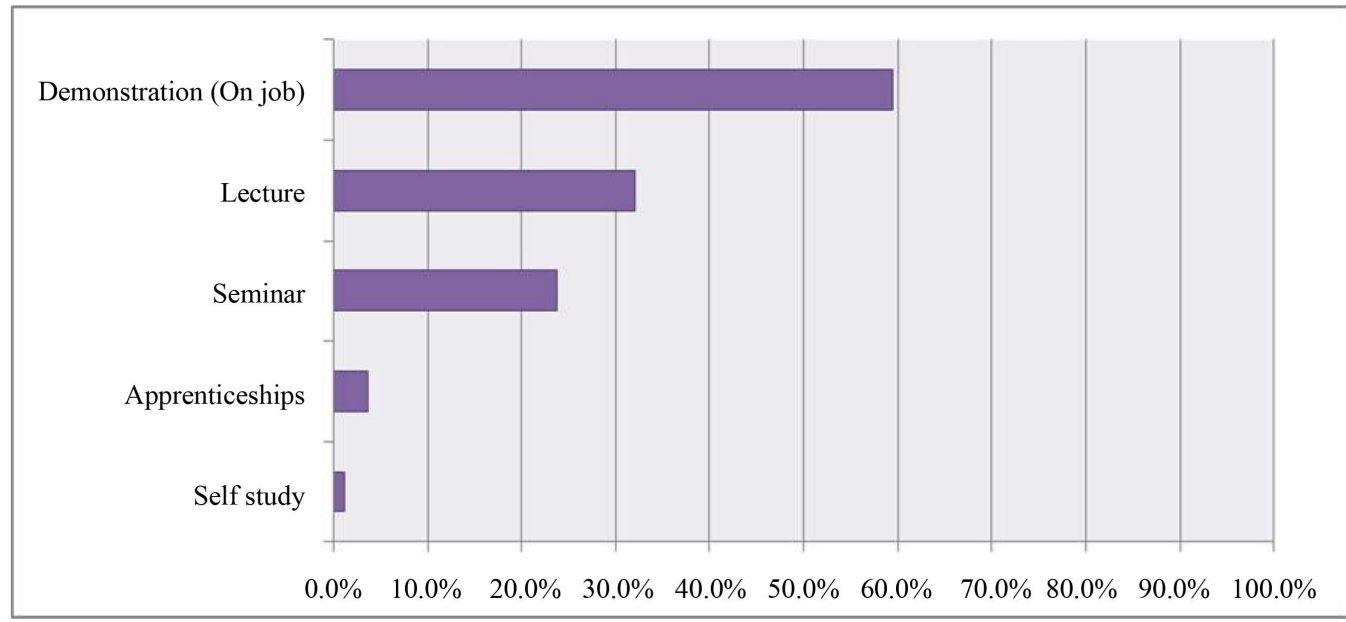

Figure 1. Bar chart showing the employed methods of training faciliation ( $\mathrm{n}=84)$, Addis Ababa, April 2014.

designed to improve the skill of employee (3.35). The second five items were about employee performance. The training improved quality of work (2.65), it reduces accidents (2.44), the training enables staff to use new tools and machines (2.19), and the training improves motivation (2.28) and improves job satisfaction (2.19). The third group was about employee effectiveness. The training increased products or services (2.60); it reduced wastes (2.78) and adds new capabilities or skills (2.64).

In this research we want to estimate the effect of training and development on employee's performance and Organizational effectiveness. Pearson correlation was computed to check whether training and development have any ecological relationship with performance and effectiveness. As depicted in the (Table 3) below the mean score for training and development with standard deviation was $11.01 \pm 3.28$, and the mean score for employee performance with standard deviation was $11.98 \pm 4.34$ and the mean score with standard deviation for employee effectiveness was $8.03 \pm 3.03$. The correlation coefficient for employee performance and employee effectiveness was 0.36 and 0.50 respectively the observed relationship is positive, which mean when the score of training and development increases the score of performance and effectiveness increase. These relationships were found statistically significant at $\mathrm{P}<0.05$. 
Since this research was designed to investigate any possible causal relationship among training and development with employee performance and effectiveness, we employed linear regression analysis. As presented below (Table 4), the effect of training and development and employee performance on employee's effectiveness was compute. The beta $(\beta)$ coefficient from the general linear models, unadjusted score for training and development with 95\% Confidence Interval (CI) was $\beta 0.46(0.28,0.63)$ while employee performance with 95\% CI was $\beta 0.49(0.39,0.60)$. And in the adjusted models the $\beta$ value for training and development was $0.25(0.11$, $0.39)$, while employee performance scored $0.42(0.32,0.53)$. The relationship was found statistically significant at $\mathrm{P}<0.05$.

\section{Discussions}

The general objective of this research was to assess the impact of training and development on employee's performance and effectiveness for the case of District Five Administration Office, Bole sub-City, Addis Ababa, Ethiopia. The majority of the respondents 84 (89.3\%) were attended trainings in the last three years. Almost every employee had opportunity to attend up to 8 trainings each year. The finding is in line with the recommendations of Jehanzeb and Beshir (2013), the role of an organization's manager should include providing others the vision and ability to perform for the successful achievement of their goal [13].

The finding of this research confirms that the training and development activities in which employees had participated brings new potentials of employees in performing task and resulted in employee effectiveness. The finding was in line with the principles of Cole (2002) suggestion on purpose of facilitating training as it was to create a learning media directed towards the acquisition of specific knowledge and skills for the purpose of an occupation or task [3].

Regarding training need assessment or identification of skill deficits were found as rarely performed activity. This could be due to that most of the civil service reform activities are derived from high level decision. On top of this based on the finding of this research the culture of training evaluation seams very low. Ongalo and Tari (2015) Confer in Kenya electricity generating and distribution firms lacked clear policies governing training and development, which had a negative effect on organizational performance [27].

Braga (1995) affirms that training delivery style is a very important part of training and development. In this study we found $59.0 \%$ of respondents cited demonstration or onsite coaching the most frequent method of training facilitation techniques. This find was in line with Braga found most of the research participants reported they were attended on job (demonstration) training, which help to transform it into practice [17].

The main variables training and development (independent variable) computed with employee performance

Table 3. Correlation between mean training and development score and other dimension of performance and effectiveness.

\begin{tabular}{clcccc}
\hline Score & \multicolumn{2}{c}{ Mean score (SD) } & $\begin{array}{c}\text { Correlation } \\
\text { coefficient (r) }\end{array}$ & P-value & $\mathrm{R}^{2}$ \\
\hline Training and development & 11.01 & 3.28 & 1.00 & & $\mathbf{0 . 0 0 1}$ \\
Employee performance & 11.98 & 4.34 & 0.36 & 0.13 \\
Organization effectiveness & 8.03 & 3.03 & $\mathbf{0 . 0 0 1}$ & 0.25 \\
\hline
\end{tabular}

All bold values are significant at $\mathrm{P}<0.05$ in the column marked $\mathrm{P}$ value.

Table 4. Unadjusted and adjusted linear regression coefficients for mean score of employee's effectiveness by dimensions of training and development \& employee performance.

\begin{tabular}{|c|c|c|c|c|c|}
\hline \multirow{2}{*}{$\begin{array}{l}\text { Dimension of organizational effectiveness } \\
\text { score }\end{array}$} & \multicolumn{2}{|c|}{ Unadjusted } & \multicolumn{2}{|c|}{ Adjusted } & \multirow{2}{*}{ P-value } \\
\hline & $\beta$ & $95 \%$ CI & $\beta$ & $95 \%$ CI & \\
\hline Training and development & 0.46 & $0.28,0.63$ & 0.25 & $0.11,0.39$ & 0.001 \\
\hline Employee performance & 0.49 & $0.39,0.60$ & 0.42 & $0.32,0.53$ & 0.001 \\
\hline Constant & & & 0.07 & $-1.60,1.76$ & 0.920 \\
\hline
\end{tabular}

NB: Positive value of $\beta$ indicates increase in mean effectiveness score per unit increase in training and development or employee performance score. All bold values are significant at $\mathrm{P}<0.05$ in the column marked $\mathrm{P}$-values. 
and employee effectiveness (dependent variable) positively correlated and the relationship was found statistically significant. The correlation coefficient was stronger for employee effectiveness $(r=0.50, P<0.000)$ with employee training and development. In similar ways the correlation coefficient between employee performance and training and development was moderate $(r=0.36, \mathrm{P}<0.001)$.

The linear regression result showed that an adjusted $\beta$ value of 0.25 and 0.42 for training and development and employee effectiveness. The result shows that a change of one standard deviation in predictor variable i.e. training and development will have a change in 0.25 times standard deviation for the dependent variable i.e. employee effectiveness. In a similar fashion a one standard deviation increase in employee performance will have resulted in a change of 0.42 times standard deviations in employee effectiveness. Hence, training and development have a positive correlation with employee performance and employee effectiveness. And this relationship is statistically significant at $\mathrm{P}<0.05$. This result was in line with a study conducted in Pakistan revealed that on job training was very effective and it saves time and cost [16]. Similarly, Madukoma, Akpa, and Okafor (2014) attest training motivates library personnel in University of Lagos to do their jobs. This relationship was found with statistically significant effect on overall organizational performance [28]. However, Zwick (2015) relate effectiveness of training with its content than the duration, financing and initiative, He state the main reason for the differences in training effectiveness during the life cycle is that firms do not take into account differences in training motivation [29].

The main finding of this research shows that training and development have a positive correlation on the outputs of employee's performance and effectiveness. This relationship was tested for causality using linear regression statistical model and found out employee effectiveness has a direct cause and effect relationship with employee performance, and training and development. Ni and Wang (2015) confer organization should have concern about the potential development and self-realization of the employees [30]. Similarly, Quartey (2012) found a moderately strong relationship between employee training and organizational performance [31]. This is in line with Ahmad and Din (2009) suggestion on the intention of providing training was to enhance the performance of employees through learning process [32]. And it is believed to have an opportunity in the acquirement of knowledge, improvement of skills, concepts, rules, changes of attitudes and behaviors in the organizational settings. Huselid (1995) affirm that providing formal and informal training for new employees have an influence on employee's development [12].

\section{Limitations}

The sample size of 100 was small for such kind of study intended but time and financial resource constraints makes it imperative to restrict the sample to that size.

\section{Conclusions}

Form this study the following points have been drawn:

$>$ In the last three years District Five Administration Office had been highly involved in providing training and staff development activities. This high level performance was reported by the majority of the respondents as they were involved in training and development interventions.

$>$ The most frequent methods of training facilitation were on job training (demonstration) and re-demonstration by trainees. We can conclude that the method of training facilitation has a successful outcome which was observed in employee performance and organizational effectiveness.

> We can conclude that the result of the Pearson correlation and linear regression for the predictor variable training development activities against the critical variable employee performance and organizational effectiveness has a positive correlation coefficient $(r>0.36)$ with statistical significant $\mathrm{P}<0.001$.

> Finally, we can conclude that the result of this study reveals that the training and development activities of District Five Administration Office have a positive outputs and outcomes. However, it needs to improve the systematic identification of the training need and skill deficit of employees, monitor and evaluate with objective tools or criteria so as the program helps to maximize the impact of training and development activities in the administration office.

\section{Recommendations}

Based on the finding of the study the following suggestions are recommended: 
$>$ The employee training and development activity shall be based on a systematically identified knowledge and skill deficit so as it maximize the effort of the both the employee and organization.

$>$ Ensuring adequate budget for training and development activities, utilizing the allocated resources in efficient manner shall be maintained for organizational success.

> Involving employees in training evaluation activities and taking inputs for future similar activities and document best practices to scale up in similar settings.

The impact of training on quality of services and client satisfaction shall be studied.

\section{Acknowledgements}

We thank all study participants for their participation in this study. We would take this opportunity to acknowledge District Five Administrative Office, Bole sub-City, Addis Ababa, Ethiopia for permission of the study.

\section{References}

[1] Armstrong, M. (2009) Armstrong's Handbook of Human Resource Management Practice. 11th Edition, Kogan Page Limited, London.

[2] Hamblin, A.C. (1974) Evaluation and Control of Training. McGraw Hill.

[3] Cole, G.A. (2002) Personnel and Human Resource Management. 5th Edition, York Publishers, Continuum London.

[4] Meyer, P.J. and Smith, A.C. (2000) HRM Practices and Organizational Commitment: Test of a Mediation Model. Canadian Journal of Administrative Sciences, 17, 319-331. http://dx.doi.org/10.1111/j.1936-4490.2000.tb00231.x

[5] McDowall, A. and Saunders, M.N.K. (2010) UK Manager's Conceptions of Training and Development. Journal of European Industrial Training, 34, 609-630. http://dx.doi.org/10.1108/03090591011070752

[6] Elnaga, A. and Imran, A. (2013) The Effect of Training on Employee Performance. European Journal of Business and Management, 5, 137.

[7] Garavan, T.N. (1997) Training, Development, Education and Learning: Different or the Same? Journal of European Industrial Training, 21, 39-50. http://dx.doi.org/10.1108/03090599710161711

[8] Berge, Z., Verneil, M.D., Berge, N., Davis, L. and Smith, D. (2002) The Increasing Scope of Training and Development Competency. Benchmarking: An International Journal, 9.

[9] Beardwell, N. and Holden, B. (1993) Managing for Success. 2nd Edition, Prentice Hall Publisher, England.

[10] Addis Ababa City Government (2013) Annual Performance Report of the Year 2006 EFY. Addis Ababa, Ethiopia.

[11] Shen, J. (2004) International Training and Management Development: Theory and Reality: A Conceptual Study. Journal of Management Development, 24, 656-666. http://dx.doi.org/10.1108/02621710510608786

[12] Huselid, M.A. (1995) The Impact of Human Resource Management Practices on Turnover, Productivity, and Corporate Financial Performance. The Academy of Management Journal, 38, 635-672. http://dx.doi.org/10.2307/256741

[13] Jehanzeb, K. and Beshir, N.A. (2013) Training and Development Program and Its Benefits to Employee Organization: A Conceptual Study. European Journal of Business and Management, 5, 243-252.

[14] Hales, L.D. (1986) Training: A Product of Business Planning. Training \& Development Journal, 40, 65-66.

[15] Sabir, R.I., Akhtar, N., Azzi, S., Sarwar, B., Zulfigar, S. and Irfan, M. (2014) Impact of Employee Satisfaction: A Study of Lahore Electric Supply Company of Pakistan. Journal of Basic and Applied Scientific Research, 4, $229-235$.

[16] Khan, R.A.G., Khan, F.A. and Khan, M.A. (2011) Impact of Training and Development on Organizational Performance. Global Journal of Management and Business Research, 11, 62-68.

[17] Braga, C.A.P. (1996) The Impact of the Internationalization of Services on Developing Countries. Finance and Development, 33, 34-37.

[18] Rahman, A.A., Ng, I.S., Sambassivan, M. and Wong, F. (2013) Training and Organizational Effectiveness: Moderating Role of Knowledge Management Process. European Journal of Training and Development, 37, 472-488. http://dx.doi.org/10.1108/03090591311327295

[19] Blain, J. (2009) Current Learning Trends in Europe and the United States. (online) https://cdns3.trainingindustry.com/media/2505191/cegos-current\%20learning\%20trends\%20in\%20europe\%20and\%20 us

[20] Tajfel, H. (1972) Social Categorization. English Manuscript of "La catégorisation sociale”. In: Moscovici, S., Ed., Introduction à la Psychologie Sociale, Vol. 1, Larousse, Paris, 272-302. 
[21] Hogg, M.A. and Terry, D.J. (2000) Social Identity and Self-Categorization Processes in Organizational Contexts. Academy of Management Review, 25, 121-140.

[22] SPSS, Inc. (2011) IBM SPSS Statistics Base 20. SPSS Inc., Chicago.

[23] Antonacopoulou, E.P. (2000) Employee Development through Self-Development in Three Retail Banks. Personnel Review, 29, 491-508. http://dx.doi.org/10.1108/00483480010296294

[24] Malik, M.E., Ghafoor, M.M. and Naseer, S. (2011) Organizational Effectiveness: A Case Study of Telecommunication and Banking Sector of Pakistan. East Journal of Psychology and Business, 2, 37-49.

[25] Jamrog, J.J. and Overhol, M.H. (2005) Measuring Organizational Effectiveness: Canadian Management Centre Special Report. (online) http://www.cmctraining.org/reg/wp/MeasuringOrganizationalEffectiveness.pdf

[26] Likert, R. (1932) A Technique for the Measurement of Attitudes. Archives of Psychology, 140, 1-55.

[27] Ongalo, E.A. and Tari, J. (2015) Effect of Employee Motivation Strategies on Organizational Performance: A Case of Electricity Generating and Distribution Firms in Kenya. European Journal of Business and Management, 7, 55-65.

[28] Madukoma, E., Akpa, V.O. and Okafor, U.N. (2014) Effect of Training and Motivation on Job Performance of Library Personnel of University of Lagos, Lagos State, Nigeria. Open Access Library Journal, 1, e804. http://dx.doi.org/10.4236/oalib.1100804

[29] Zwick, T. (2015) Training Older Employees: What Is Effective? International Journal of Manpower, 36, 136-150. http://dx.doi.org/10.1108/IJM-09-2012-0138

[30] Ni, C. and Wang, Y. (2015) The Impact of Perceived Organizational Support and Core Self-Evaluation on Employee’s Psychological Well-Being. Journal of Human Resource and Sustainability Studies, 3, 73-81. http://dx.doi.org/10.4236/jhrss.2015.32011

[31] Quartey, S.H. (2012) Effect of Employee Training on the Perceived Organisational Performance: A Case Study of the Print-Media Industry in Ghana. European Journal of Business and Management, 4, 77-87.

[32] Ahmad, I. and Din, S. (2009) Evaluating Training and Development. Gomal Journal of Medical Sciences, 7, $165-166$. 


\section{Annexure One-Tool for Employee}

Introduction: My name is Abeba Mitiku I am MBA student at FAEM and IICM. I am hereto collect data for the research work, and one to one interviewing with employees on the impact of training and development on their performance and their organization effectiveness and efficiency. You are selected to be one of the participants in the study. The study will be conducted through interview. Your name is not going to be required (registered) and the information you give us should be kept confidential and will be used only for study purpose. A code number will identify every participant and no names will be used. If a report of the result is published, only summarized information of the total group will appear. The interview is voluntary; you have the right to participate, or not to participate (refuse to do so) at any time during the interview. Your refusal will not have any effect on services and benefit that you receives from your organization. However, your participation is important to fulfill the study and in order to help design appropriate intervention to promote organizational effectiveness and efficiency through training and development.

A. Was the information/objective clear?

1. Yes. B. No.

B. Are you willing to participate in the study?

1. Yes. B. No Thank you!!

If the study subject agrees to participate in the study, start the interview.

C. Interviewer signature certifying that the informed consent has been given verbally.
a. Name Signature
b. Code....
c. Date. Month. 2014
D. Result

A. Completed. B. Respondent not available C. Refused.

D. Partially completed. E. Other (please specify)

E. Checked by supervisor

Name. Signature. Date

Part I. Interviewer administered questionnaire for employee.

\begin{tabular}{|c|c|c|c|c|}
\hline$\#$ & Question item & Response & Cod No. & Skip to \\
\hline 001 & Study record & & & \\
\hline 002 & Region & Addis Ababa City Administration & & \\
\hline 003 & Sub city & Bole & & \\
\hline 004 & Woreda & 5 & & \\
\hline
\end{tabular}

1: Background information

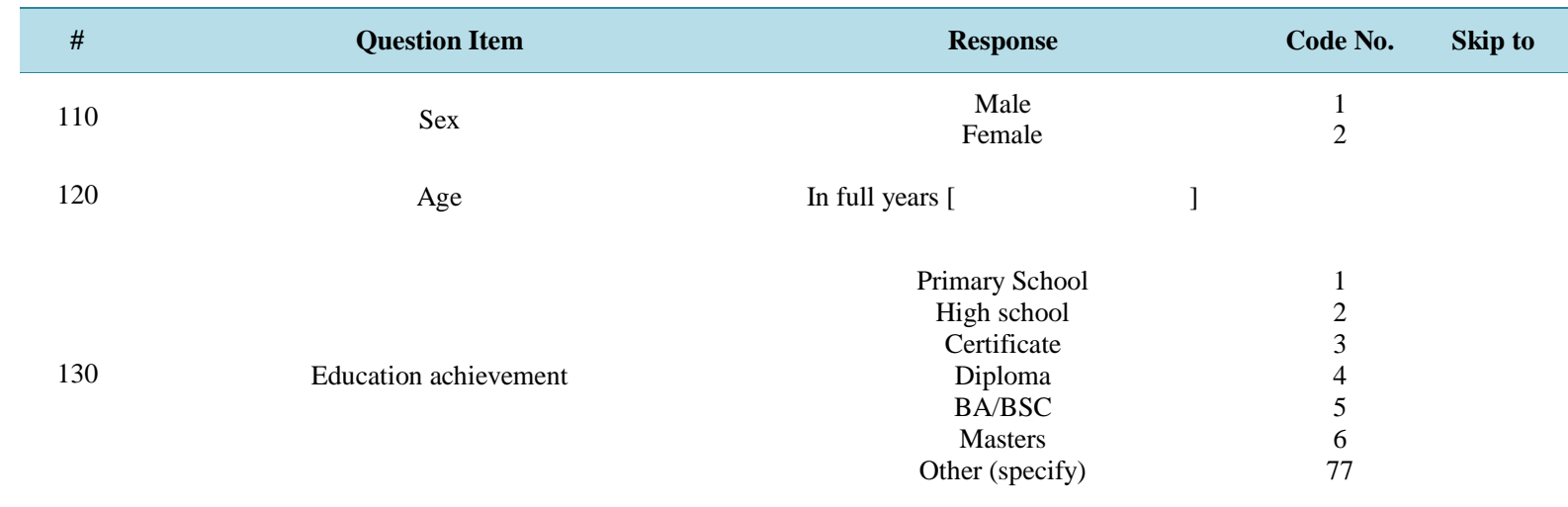




\section{Continued}

140

Marital Status

150

Please indicate your status within your organization;

160

170

180

190

200

210

How oftne your organization conduct a peformance effectiveness assessmetn to assess the ccurrent situation?

Please specify your position in Woreda Five Administrative office

How long have you worked in this post?

How many years of services do you tenured?

How much do you incur (monthly income)

In the last three years, have ever got training/orientation on related to your job?

If you answer Q 200 yes, how many times do you have taken training?

If you answer Q 200 yes, how many times do you have taken training?

If you answer Q 200 yes, what methods were used for the faciliation?

How often does your organization identify the actual business/organization needs that the requested training program ultimately hopes to achieve?
Single

Married

Divorced

Widowed

Top Management

Middle Management

Lower Management/Supervisor

Professional/Technical staff

Support staff

Other (please specify)

Does your organization have a clear and defined strateiy related to human resource development?
[

[

[

[

$$
\text { no }
$$

1
2

[

[

] number

] days

$\begin{array}{cc}\text { Computer } & 1 \\ \text { Accounting } & 2 \\ \text { Operational } & 3 \\ \text { Professional/technical } & 4 \\ \text { Team building } & 5 \\ \text { Leadership and Management } & 6 \\ \text { Other (Specify) } & 77\end{array}$

$\begin{array}{cc}\text { Never } & 1 \\ \text { Rarely } & 2 \\ \text { Sometimes } & 3 \\ \text { Mostly } & 4 \\ \text { Always } & 5\end{array}$




\section{Questionnaire on Training}

The following questions describe the organizations effort to train its employees. Please put " $X$ " in the space at the front of the questions under number you think express the position of the organization in relation to the training program?

Assume 1 = Never 2 = rarely $3=$ sometime $4=$ often 5 = always and put on the remark column "NA" if not applicable. "DN" for you do not know.

\begin{tabular}{|c|c|c|c|c|c|c|c|}
\hline \multirow[t]{2}{*}{$\#$} & \multirow{2}{*}{$\begin{array}{c}\text { Question item } \\
\text { Descriptions }\end{array}$} & \multicolumn{6}{|c|}{ Your opinion/position } \\
\hline & & 1 & 2 & 3 & 4 & 5 & Remark \\
\hline 300 & $\begin{array}{l}\text { Do you think the training program designed based on the requirements of the } \\
\text { job? Or employee deficiency of ability for the job? }\end{array}$ & & & & & & \\
\hline 310 & Is the type of training you have taken applicable for the job after the training? & & & & & & \\
\hline 320 & Do you have known the objective of the training? & & & & & & \\
\hline 330 & Does the training increase your motivation to the job you do? & & & & & & \\
\hline 340 & Does training improves your skills, knowledge, attitude change, new capability & & & & & & \\
\hline 350 & Does the training lead you to be satisfied with your job? & & & & & & \\
\hline 360 & Do you think the method of training used by the organization is effective & & & & & & \\
\hline 370 & Do you have enough training that enables you to do your job as required? & & & & & & \\
\hline 380 & Do you think the expenditure for employee training is enough? & & & & & & \\
\hline 390 & Does the training program evaluate during or at the end of the program? & & & & & & \\
\hline 400 & Do you think that the organization is effective from the training expenditure? & & & & & & \\
\hline 410 & $\begin{array}{l}\text { Are you satisfied with the overall aspect } \\
\text { of the training programs in the organization? }\end{array}$ & & & & & & \\
\hline 420 & $\begin{array}{l}\text { In your opinion, do you think the organization is } \\
\text { effective from the training expenditure? Yes/No. why? }\end{array}$ & 1. Yes & No & & & Why? & \\
\hline
\end{tabular}

\section{Questionnaire on Workers Performance}

The following phrases evaluate the return of the training relative to its objective of training and impact on the organization. Please answer by putting " $\mathrm{X}$ " in the box you think represent the result of the training in front of each question.

Assume objective: $1=$ Very low $2=$ Low $3=$ Moderate $4=$ High $5=$ Very High and put on the remark column "NA" if not applicable. "DN" if you do not know.

\begin{tabular}{|c|c|c|c|c|c|c|c|}
\hline \multirow[t]{2}{*}{ \# } & \multirow{2}{*}{$\begin{array}{c}\text { Question item } \\
\text { Descriptions }\end{array}$} & \multicolumn{6}{|c|}{ Your opinion/position } \\
\hline & & 1 & 2 & 3 & 4 & 5 & Remark \\
\hline 500 & In my opinion training helps me to increase productivity & & & & & & \\
\hline 510 & $\begin{array}{l}\text { The training I received helped me to enhance high quality } \\
\text { of product/service }\end{array}$ & & & & & & \\
\hline 520 & $\begin{array}{l}\text { The training provided by my organization helped me to improve } \\
\text { quantity }\end{array}$ & & & & & & \\
\hline 530 & $\begin{array}{l}\text { I feel the training enables me to improves skills, knowledge, } \\
\text { attitude change, new capability }\end{array}$ & & & & & & \\
\hline 540 & $\begin{array}{l}\text { In my opinion training helps me to enhance the use of } \\
\text { tools and machine, operational safety }\end{array}$ & & & & & & \\
\hline 550 & After the training I feel it reduces possible accidents & & & & & & \\
\hline
\end{tabular}




\section{Continued}

560 I have a good relationship with my supervisor and the training reduces lateness, absenteeism

570 The training provided helped me to eliminates obsolesce in skills,

580 In my opinion training helps me to reduction in errors

590

In my opinion training helped me to reduce frequency of supervision

600 In my opinion training helps me to reduction in turnover

610 I feel a string sense of belonging to this organization and the training helps me to improve my motivation to work

620 In my opinion training helps me to decrease material wastage

630 In my opinion training helps me to increase job satisfaction

640 I am confident that the training brings strong team work so as it helped my organization training increase work efficiency

650

I feel the training provided helped my organization to ensure its success with client satisfaction.

Thank you! 